\title{
Efficacy and economics of integrated weed management in groundnut (Arachis hypogea L.)
}

\author{
Oludamilola ADEMABAYOJE ${ }^{1}$, Joseph ADIGUN ${ }^{1}$, Olusegun ADEYEMI ${ }^{1}$, Olumide DARAMOLA ${ }^{1,2}$, \\ Godwin AJIBOYE ${ }^{3}$
}

Received April 8, 2020, accepted August 12, 2020.

Delo je prispelo 08. aprila 2020, sprejeto 12. avgusta 2020. Efficacy and economics of integrated weed management in
groundnut (Arachis hypogea L.)

Abstract: Weed management is an important and expensive step in groundnut production. Field experiments were conducted in the early and late wet seasons of 2017 to evaluate the effectiveness and profitability of weed management using hoe weeding, herbicides or their combination in groundnut production. Butachlor and propaben at $2.0 \mathrm{~kg}$ a.i (active ingredient) $\mathrm{ha}^{-1}$ each followed by (fb) supplementary hoe-weeding (shw) at 6 weeks after sowing (WAS) significantly reduced weed cover and biomass with subsequent increase in groundnut pod yield similar to hoe-weeding treatments and better than either herbicide applied alone. The highest groundnut pod yield $\left(1485.7 \mathrm{~kg} \mathrm{ha}^{-1}\right)$ and revenue (\$1639.2) in the early season was obtained with three hoe weeding passes. However, in the late season, the highest groundnut pod yield (1146.3 $\left.\mathrm{kg} \mathrm{ha}^{-1}\right)$ was obtained with propaben plus hoe-weeding and the highest revenue (\$1264.8) obtained with butachlor plus hoe-weeding. Although three hoe-weedings gave the highest revenue in the early season, the gross margin and cost-benefit ratio obtained with hoe weeding treatments was lower than those of herbicides $\mathrm{fb}$ shw. This study showed that integrated weed management with butachlor or propaben and fb shw will improve weed control, productivity and profitability of groundnut production. Multiple hoe weeding, however, did not guarantee the highest profit but rather increased the cost of production.

Key words: butachlor; economics; efficacy; herbicides; hoeing; integrated weed management; propaben
Učinkovitost in ekonomičnost integriranega upravljanja $s$ pleveli pri pridelavi arašidov (Arachis hypogea L.)

Izvleček: Upravljanje s pleveli je pomemben in drag korak pri pridelavi arašidov. $\mathrm{V}$ ta namen je bil izveden poljski poskus v zgodnji in pozni deževni dobi 2017 za ovrednotenje učinkovitosti in donosnosti upravljanja s pleveli v pridelavi aršidov z okopavanjem, herbicidi in njuno kombinacijo. Uporabi butaklora in propabena pri 2,0 kg (aktivne snovi) ha-1 je v obeh primerih sledilo še dodatno okopavanje 6 tednov po setvi, kar je značilno zmanjšalo pokrovnost in maso plevelov s povečanjem pridelka strokov arašidov, ki je bil podoben tistemu, kjer je bilo samo okopavanje, a boljši kot pri uporabi samo katerega od herbicidov. Največji pridelek strokov arašidov $\left(1485,7 \mathrm{~kg} \mathrm{ha}^{-1}\right)$ in donos $(\$ 1639,2)$ je bil v zgodnji sezoni dosežen s tremi okopavanji. $\mathrm{V}$ pozni sezoni je bil največji pridelek strokov arašidov $\left(1146,3 \mathrm{~kg} \mathrm{ha}^{-1}\right)$ dosežen $\mathrm{z}$ uporabo propabena $\mathrm{z}$ dodatnim okopavanjem in največji donos $(\$ 1264,8)$ pri uporabi butaklora $\mathrm{z}$ dodatnim okopavanjem. Čeprav so dala trikratna ročna okopavanja največji donos v zgodnji sezoni sta bila neto dobiček in razmerje stroškov in dohodkov pri okopavanju manjša kot pri uporabi herbicidov $\mathrm{z}$ dodatnim okopavanjem. Raziskava je pokazala, da bi pri integriranem uravnavanju plevelov z butaklorom ali s propabenom dodatno okopavanje izboljšalo nadzor nad pleveli, povečalo pridelavo in donosnost pridelave arašidov. Večkratno zatiranje plevelov samo z okopavanjem ni zagotovilo večjega dobička ampak je povečalo stroške pridelave.

Ključne besede: butaklor; ekonomičnost; učinkovitost; herbicidi; okopavanje; integrirano upravljanje s pleveli; propaben

1 Federal University of Agriculture Abeokuta, Department of Plant Physiology and Crop production

2 Corresponding author, e-mail: olumidedara01@gmail.com

3 Federal University of Agriculture Abeokuta, Department of Soil Science 


\section{INTRODUCTION}

Groundnut (Arachis hypogea L.) is one of the most important grain legume and oilseed crops of tropical and semiarid tropical countries, where it provides a major source of edible oil and vegetable protein (Sogut et al., 2016). The kernels are rich in oil (48-50 \%) and protein (25-28\%), and are source of several vitamins, minerals, antioxidants, biologically active polyphenols, flavonoids, and isoflavones (Janila et al., 2013). It provides income and livelihoods to the farmers, nutritious fodder (haulms) to livestock, and contributes to nutrition of farm families through consumption of energy- and protein-rich groundnut kernels (Birthal et al., 2011). In addition, groundnut fixes atmospheric nitrogen for its own use and the benefit of intercropped cereals and subsequent crops in rotation (Bado at al., 2006). This makes it an important crop for soil fertility improvement especially for smallholder farmers who are often unable to afford synthetic nitrogen fertilizers.

Groundnut is grown on 27.7 million ha in the world with production of about 44 million tons. Nigeria, with about 3 million tons production is the largest producer of groundnut in Africa, and the third largest producer in the world after China (16.7 million tons) and India (6.9 million tons) (FAOSTAT, 2018). Despite the increased importance of groundnut, yield obtained from farmer's field in Nigeria and other parts of Africa are very low. In general, groundnut productivity in Africa has the lowest average yield (902.6 $\left.\mathrm{kg} \mathrm{ha}^{-1}\right)$ compared to America (3381.4 kg ha-1), Asia (2186.8 kg ha-1), Oceania $\left(1947.3 \mathrm{~kg} \mathrm{ha}^{-1}\right)$, Europe $\left(3102.1 \mathrm{~kg} \mathrm{ha}^{-1}\right)$, and the global average yield (1590.1 $\mathrm{kg} \mathrm{ha}^{-1}$ ) (FAOSTAT, 2018). Several biotic, abiotic and socio-economic constraints are responsible for the low yield of groundnut in Africa. Among biotic factors, weed interference is the most deleterious, causing yield reduction from the range of 13 to $100 \%$ depending on the season, cultivars, weed composition and duration of crop-weed competition (Adigun et al., 2016; Ojelade et al., 2018). Weeds exert severe competition for nutrients, water and light, hinder pegging, compete for underground space, and make harvesting of groundnut cumbersome (Jat et al., 2011).

Hoe weeding is the predominant weed control method commonly used by farmers in Nigeria (Imoloame, 2014; Daramola et al., 2020). Although hoe weeding is very important when trying to avoid the development of potential serious weed problems, its efficacy is often compromised by the continued wet condition characteristic of the beginning of the rainy season. Hoe weeding under wet condition often causes weed to re-root and reestablish, necessitating several rounds of weeding to keep the crop weed-free and avert yield losses. This is however, tedious, inefficient, time consuming and associated with high labour demands (Datta et al., 2017; Adigun et al., 2018). In addition, labour for manual weeding is scarce and often too expensive for the average farmer to afford (Adigun et al., 2017).

Alternatively, the use of herbicides is fast and quite effective in suppressing weeds if used at the proper rate and time (Chauhan et al., 2012). Controlling weeds using herbicides reduces drudgery, protect crops from early weed competition and may minimize labour cost (Adigun et al., 2018). However, a single herbicide application may not control the entire weed spectrum with diverse physiology, morphology and time of emergence (Chauhan et al., 2012; Bhagirath et al., 2013). Herbicides efficacy is further limited under conditions of high rainfall and prolonged weed germination period (Daramola et al., 2019). Moreover, indiscriminate use of herbicide can result in unintended adverse consequences such as toxicity to off-site or non-target flora and fauna, declining species diversity and herbicide resistance (Chauhan et al., 2012; Adigun et al., 2018). Hence, the need to combine two or more weed management components for broad spectrum weed control.

Combination of reduced number of hoe-weeding passes and/or herbicide applications within the context of integrated weed management could help to improve weed control efficiency, reduce the high cost associated with multiple hoe-weeding or herbicide applications and increase groundnut yield. Although few studies (Adigun et al. 2017; Daramola et all., 2020) have reported increased weed control efficiency and higher yields with integrated weed management, economic consideration, particularly profit is more important to farmers in driving the adoption of agricultural innovation (Pannell et al. 2006). It has also been reported that practice with the best yield may not necessarily translate to the best economic benefit to farmers (Sepat et al. 2017). Hence, this study was conducted to evaluate the efficacy and economic performance of weed management methods using hoe weeding, herbicides or their combination in groundnut production.

\section{MATERIALS AND METHODS}

Two field studies were carried out at the University of Agriculture Abeokuta at latitude $7^{\circ} 15^{\prime} \mathrm{N}$ and longitude $3^{\circ} 25^{\prime} \mathrm{E}$ in south western Nigeria during the early (June - September) and late (August - November) seasons of 2017. During this period, total rainfall was 538 and $431 \mathrm{~mm}$, minimum temperature was 22.1 and $19.0^{\circ} \mathrm{C}$ and maximum temperature was 25.0 and $29.0^{\circ} \mathrm{C}$, in the early and late seasons, respectively. The soil of the sites 


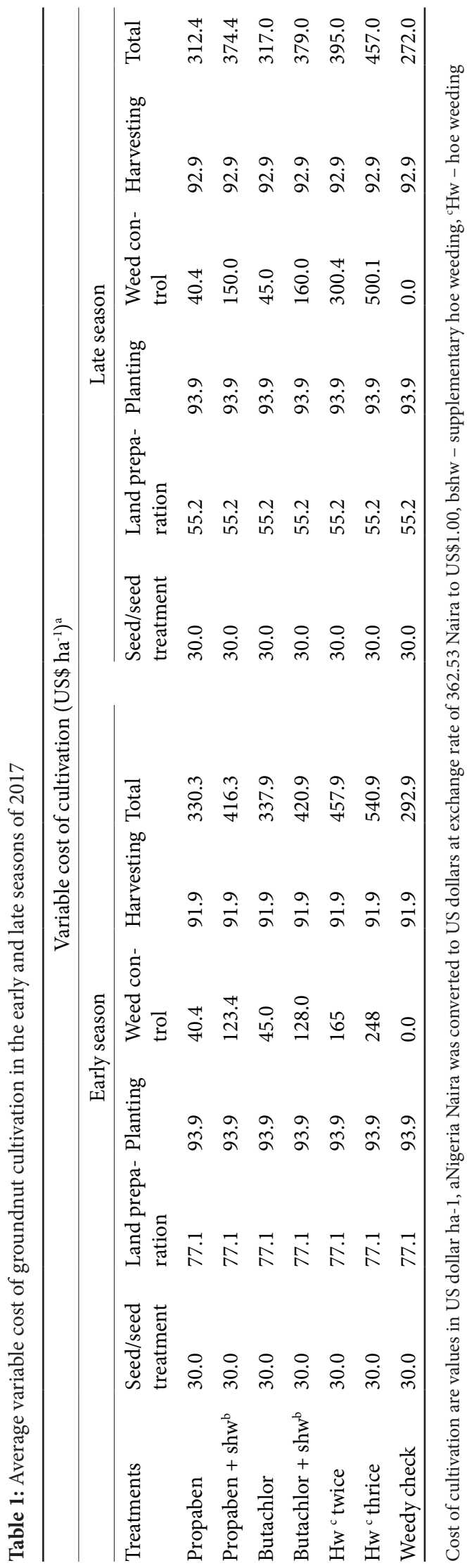

was sandy loam with $\mathrm{pH}$ of 6.9 and 7.1, total nitrogen of 0.23 and $0.21 \%$ and organic matter of 2.3 and $2.2 \%$ in the early and late seasons, respectively. The study sites was cleared manually while ploughing and harrowing were done mechanically at two weeks' interval.

The study consisted of six weed management methods viz: butachlor at $2 \mathrm{~kg}$ a.i (active ingredient) ha ${ }^{-1}$; butachlor at $2 \mathrm{~kg}$ a.i ha ${ }^{-1}$ followed by (fb) supplementary hoe weeding (shw) at 6 weeks after sowing (WAS); propaben at $2 \mathrm{~kg}$ a.i ha- ${ }^{-1}$; propaben at $2 \mathrm{~kg}$ a.i ha ${ }^{-1} \mathrm{fb}$ shw at $6 \mathrm{WAS}$; hoe weeding twice at 3 and 6 WAS; hoe weeding thrice at 3, 6 and 9 WAS and the weedy check where no weed removal was done throughout the period of crop growth. Butachlor and propaben were applied pre-emergence one day after the groundnut seeds were sown. Data on weed cover score and dry weed biomass $\left(\mathrm{g} \mathrm{m}^{-2}\right)$ were taken at 12 WAS. Weed cover score was accessed by visual estimate based on a scale of $0-10$ : where 0 represents no weed growth and 10 represents complete weed cover (Kercher et al., 2003; Tunku et al., 2007). Weed cover is usually referred to as the area of ground covered by weeds or the relative proportion of weed coverage within the plot when viewed from above (Nikoa et al., 2015). Weeds were sampled from a $50 \mathrm{~cm}^{2}$ quadrat randomly placed at three spots within the plots. The sampled weeds were oven-dried at $70^{\circ} \mathrm{C}$ until constant mass was reached, and the resulting weight recorded in $\mathrm{g} \mathrm{m}^{-2}$.

Groundnut pods were harvested from each plot when the leaves had turned brown in both seasons. The cumulative pod mass in $\mathrm{kg}$ plot $^{-1}$ were then expressed in $\mathrm{kg} \mathrm{ha}^{-1}$. Statistical analysis (ANOVA) was done with GENSTAT package while Least Significant Difference (LSD at $p \leq 0.05$ ) was used to separate the treatment means. Prevailing market prices of all inputs and cost of labour in Nigeria in the early and late seasons of 2017 were used to evaluate the cost of groundnut cultivation (Table 1). The cost of propaben and butachlor each at $2.0 \mathrm{~kg}$ a.i ha ${ }^{-1}$ was $\$ 23.8$ and $\$ 28.4$, respectively in the early and late seasons. Application of each herbicide required 3 mandays ha ${ }^{-1}$ at the cost of $\$ 16.6$ in both early and late season. In the early season, hoe weeding once, twice and thrice required 15, 30 and 45 mandays ha $^{-1}$ at $\$ 83, \$ 165$ and $\$ 248$, respectively, considering the wages of $\$ 5.5$ per manday. However, in the late season it was at the cost of $\$ 62, \$ 123$ and $\$ 185$, respectively, considering the wages of $\$ 4.1$ per manday (Table 1). Cost of seed, sowing, land preparation, planting and harvesting were the same across all the weed management treatments (Table 1). Revenue from each weed management method was the product of groundnut pod yield $(\mathrm{kg})$ and steady market price $\left(\$ 1.1 \mathrm{~kg}^{-1}\right)$. The gross margin was used to determine the profitability of groundnut under the different weed management methods. The gross margin is 
usually referred to as returns over variable cost and services as a proxy measure of profitability (Maurice et al. 2005).

\section{RESULTS AND DISCUSSION}

\subsection{WEED SPECIES COMPOSITION}

Nineteen (19) weed species were recorded during the period of crop growth in both seasons. The weed species comprised of 10 broadleaf weeds, 7 grasses and 2 sedges (Table 2). The prevalence of both annual and perennial broadleaved weeds and grasses in this study may be a result of increased soil disturbance from previous tillage (Menallad et al., 2001). The weed species were generally more abundant in the early than in the late season. Commelina benghalensis L., Gomphrena celosioides Mart., Boerhavia diffusa L., Talinum triagulare (Jacq.) Willd., Chromolaena odorata (L.) R.M.King \&
H.Rob and Digitaria horizontalis Willd. which had high infestation in the early season were found with moderate infestation in the late season. This was possibly because the rainfall was generally more abundant and evenly distributed in the early season compared with the late season. It has been reported that rainfall affects weed species distribution and their competitiveness within a crop community (Shaidul et al., 2011).

\subsection{EFFECT OF WEED MANAGEMENT METH- ODS ON WEED COVER SCORE AND BIO- MASS}

Butachlor and propaben and hoe-weeding treatments resulted in significant reduction in weed cover score and biomass compared with the weed check in early and late season (Table 3). Sole application of butachlor and propaben each at $2 \mathrm{~kg}$ a.i ha ${ }^{-1}$ reduced weed cover score similar to two hoe-weedings in both seasons.

Table 2: Weed species and their level of infestation in the early and late wet seasons of 2017

\begin{tabular}{|c|c|c|c|}
\hline \multirow{2}{*}{$\frac{\text { Weed species }}{\text { Broad leaf weeds }}$} & \multirow[t]{2}{*}{ Plant family } & \multicolumn{2}{|c|}{ Level of infestation ${ }^{\mathrm{a}}$} \\
\hline & & Early & Late \\
\hline Tridax procumbens Linn. & Asteraceae & $* * *$ & $* * *$ \\
\hline Euphorbia heterophylla Linn. & Euphorbiaceae & $* * *$ & $* * *$ \\
\hline Commelina benghalensis Burn. & Commelinaceae & $* * *$ & ** \\
\hline Gomphrena celosioides Mart. & Amaranthaceae & $* * *$ & ** \\
\hline Spigelia anthelmia Linn. & Loganiaceae & $* * *$ & $* * *$ \\
\hline Boerhavia diffusa Linn. & Nyctaginaceae & $* * *$ & ** \\
\hline Chromolaena odorata (L.) R. M. King and Robinson & Asteraceae & $* * *$ & ** \\
\hline Talinum triagulare (Jacq.) Willd. & Portulacacae & $* * *$ & ** \\
\hline Laportea aestuans (Linn.) Chew. & Urticaceae & $* *$ & ** \\
\hline Ipomoea triloba Linn. & Convolvulaceae & ** & ** \\
\hline \multicolumn{4}{|l|}{ Grasses } \\
\hline Digitaria horizontalis Willd. & Poaceae & $* * *$ & $* *$ \\
\hline Panicum maximum Jacq. & Poaceae & $* * *$ & $* * *$ \\
\hline Axonopus compressors (Sw.) P. Beauv. & Poaceae & $* * *$ & $* * *$ \\
\hline Eleusine indica Gaertn. & Poaceae & ** & ** \\
\hline Rottboellia cochinchinensis (Lour.) Clayton & Poaceae & * & * \\
\hline Cynodon dactylon (Linn) Pers. & Poaceae & $* * *$ & $* * *$ \\
\hline Paspalum scrobiculatum Linn. & Poaceae & $* *$ & ** \\
\hline \multicolumn{4}{|l|}{ Sedge } \\
\hline Cyperus rotundus Linn. & Cyperaceae & $* *$ & ** \\
\hline Cyperus esculentus Linn. & Cyperaceae & $* *$ & ** \\
\hline
\end{tabular}

${ }^{a}$ Level of weed infestation was based on weed ground cover: ${ }^{* * *}$ - Highly infested (60-90\%), $\quad{ }^{* *}$ - Moderately infested (30-59 \%), ${ }^{*}$-Low infestation $(1-29 \%)$ 
Table 3: Effect of weed management methods on weed cover score, dry weed biomass and groundnut fresh pod yield

\begin{tabular}{lllllll}
\hline & \multicolumn{2}{l}{ Weed cover score $^{\mathrm{a}}$} & \multicolumn{2}{l}{${\text { Weed biomass }\left(\mathrm{g} \mathrm{m}^{-2}\right)}^{2}$} & \multicolumn{2}{l}{${\text { Groundnut pod yield }\left(\mathrm{kg} \mathrm{ha}^{-1}\right)}^{2}$} \\
\cline { 2 - 7 } & Early season & Late season & Early season & Late season & Early season & Late season \\
\hline Butachlor & 6.6 & 7.2 & 153.0 & 178.2 & 722.9 & 524.2 \\
Butachlor + shw ${ }^{\mathrm{b}}$ at 6 WAS & 3.2 & 3.6 & 100.9 & 70.7 & 1192.3 & 1136.7 \\
Propaben & 6.1 & 7.1 & 146.9 & 162.2 & 561.8 & 405.8 \\
Propaben + shw ${ }^{\mathrm{b}}$ at 6 WAS & 4.4 & 4.7 & 131.1 & 93.8 & 1217.3 & 1146.3 \\
Two hoe-weedings & 6.4 & 6.7 & 110.4 & 97.1 & 1144.6 & 1089.4 \\
Three hoe-weedings & 2.7 & 3.0 & 119.4 & 71.3 & 1285.7 & 998.8 \\
Weedy check & 8.5 & 8.1 & 206.1 & 230.1 & 402.1 & 287.8 \\
LSD (5 \%) & 0.93 & 0.845 & 22.6 & 20.4 & 336.2 & 332.8 \\
\hline
\end{tabular}

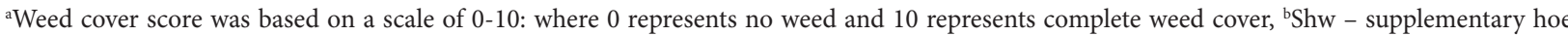
weeding; ${ }^{c}$ WAS - weeks after sowing.

This may be as a result of the efficacy of the herbicides in inhibiting weed root elongation, protein synthesis and other processes of blocking of weed development (Daramola et al., 2020). Butachlor and propaben at $2 \mathrm{~kg}$ a.i ha-1 each $\mathrm{fb}$ shw at 6 WAS reduced weed cover score similar to three hoe-weeding and better than two hoe-weeding or sole application of either herbicide in both seasons. Similarly, butachlor and propaben each followed by supplementary hoe-weeding resulted in significant reduction in weed biomass similar to two and three hoe-weeding and better than sole application of either herbicide in both early and late wet seasons (Table 3). This showed that sole herbicide application could not provide complete weed control without supplementary hoe weeding. The herbicides provided initial management of germinating weed seedlings but lost efficacy thereafter, thus allowing weed resurgence. The lowest weed biomass (100.9 and $70.7 \mathrm{~g} \mathrm{~m}^{2}$ in the early and late seasons, respectively) was recorded in plots treated with butachlor fb shw at 6 WAS. The efficacy of this treatment may be attributed to the suppression of weeds by the herbicide at the start of groundnut growth and the removal of weeds by the supplementary hoe-weeding later in the growing season, both of which helped to control weeds before setting seed and gave the crop a competitive advantage over weeds coming in the second flush. These results have corroborated the results from report of Daramola et al. (2020) that integration of herbicide application and hoe weeding is superior to sole herbicide or sole manual hoe weeding.

\subsection{EFFECT OF WEED MANAGEMENT METH- ODS ON GROUNDNUT YIELD}

Regardless of the weed management method used, groundnut pod yield was higher in the early season than in the late season (Table 3 ). This was possibly because the rainfall was more abundant and evenly distributed in the former than in the later part of the season. All the weed management methods resulted in significantly higher groundnut pod yield than the weedy check in both seasons (Table 3 ). This result is in agreement with that of Ojelade et al. (2018) who reported increased yield of groundnut due to various weed control treatments owing to the increased availability of nutrient, light and space. Although manual hoe-weeding or sole herbicide application is presently the most common weed management method in groundnut production in Nigeria, the result of this study, showed that pre-emergence application of butachlor and propaben each followed by supplementary hoeing at 6 WAS resulted in significant increase in groundnut pod yield similar to two and three hoe-weedings and higher than sole herbicide application in both early and late cropping seasons (Table 3 ). This was probably because sole application of propaben or butachlor provided weed management only at the time of weed germination and shortly after emergence, but not at later stages of crop growth, when broad-leaved weeds with relatively late emergence pattern start to emerge. These results have corroborated the report of Mishra et al. (2017) that no single method, whether manual or chemical can provide the desired level of weed control efficiency under all situation.

In this study, the highest groundnut pod yield ( $1285.7 \mathrm{~kg} \mathrm{ha}^{-1}$ ) in the early season was recorded with three hoe-weedings. However, in the late season, the highest groundnut pod yield (1146.3 $\mathrm{kg} \mathrm{ha}^{-1}$ ) was recorded with pre-emergence application of propaben plus hoe weeding. Optimum groundnut pod yield recorded with three hoe-weedings and pre-emergence herbicides plus hoe-weeding may be attributed to their efficiency in reducing weed growth throughout the prolonged period of 


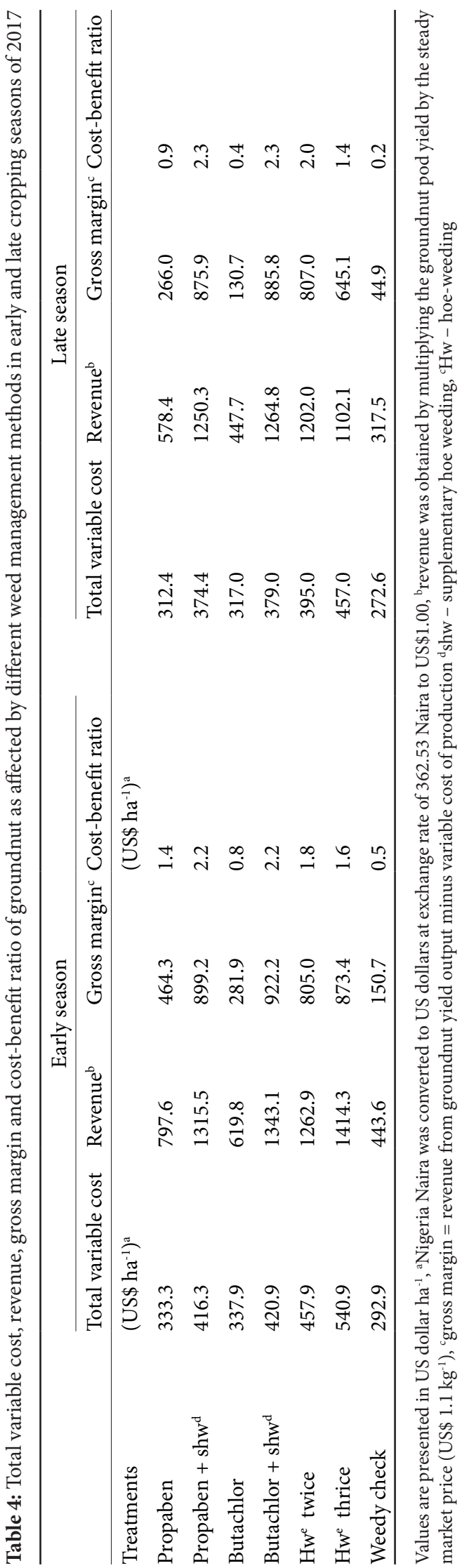

crop growth, which probably led to increased supply and use of growth resources (Khaliq et al., 2012). Unchecked weed growth throughout the period of crop growth reduced groundnut pod yield by 72.9 and $74.8 \%$ in the early and late seasons, respectively (Table 3).

\subsection{EFFECT OF WEED MANAGEMENT METHODS ON COST OF PRODUCTION AND PROFIT- ABILITY OF GROUNDNUT}

The weed management methods incurred higher cost of production than the weedy check (Table 4). This showed that the cost of weed management takes bulk of the total production cost as earlier reported by Adigun and Lagoke (2003). Regardless of the weed management methods, the total cost of production was generally lower in the late compared to the early cropping season (Table 3 ). This may be due to the reduction in cost of weed management occasioned by the reduced weed growth in the former than in the latter. This result have corroborated that of Adigun and Lagoke (2003) who reported that crop production is more cost effective in the early season than in the late season due to reduction in weed growth in the former than in later. Butachlor and propaben each applied alone at $2 \mathrm{~kg}$ a.i ha ${ }^{-1}$ or followed by hoe-weeding incurred lower cost of production than two and three hoe-weedings in both seasons (Table 4). This may be attributed to the reduction in labor requirement for herbicide application compared with the labor required for multiple hoeweedings. Overfield et al. (2001) have earlier reported that herbicide application required 1.3 person-days ha $^{-1}$ while manual hoe weeding required 39.2 person-days $\mathrm{ha}^{-1}$. The result of this study is also in agreement with the report of Gouse et al. (2006) that weed removal through herbicide application required only 2 hours of labor per hectare, whereas manual hoe-weeding required 250 hours. Of all the weed management methods, three hoe-weeding incurred the highest cost of production ( $\$ 540.0$ and $\$ 457.0$ $\mathrm{ha}^{-1}$ in early and late seasons, respectively) followed by two hoe-weedings ( $\$ 457.9$ and $\$ 395.0 \mathrm{ha}^{-1}$ in early and late seasons, respectively. Higher cost of production incurred with hoe-weedings compared with herbicidal treatment may be attributed to the accumulated cost of manual hoe-weeding which is usually expensive. This result is in agreement with that of by Adigun and Lagoke (2003), who reported that hoe weeding is expensive and causes a lot of drudgery.

There was higher total revenue and gross margin in the early season than in the late season (Table 4). This was probably as a result of higher yield occasioned by better rainfall in the former than in the latter. Butachlor and propaben at $2 \mathrm{~kg}$ a.i ha ${ }^{-1}$ each followed by hoe weeding gave higher total revenue and gross margin than two 
hoe-weeding or sole application of either herbicide in both early and late season. These treatments also gave higher total revenue, gross margin and cost-benefit ratio than three hoe weeding in the late season. Highest total revenue (\$1414.3) in the early season was recorded with three hoe weedings while the highest total revenue $(\$ 1264.8)$ in the late season was recorded with butachlor plus hoe weeding. Although three hoe-weedings gave the highest revenue in the early season, the gross margin and cost-benefit ratio obtained was lower than those of propaben and butachlor each followed by supplementary hoe eeding. Similarly, three hoe weeding gave lower gross margin and cost-benefit ratio than two hoe-weeding and propaben or butachlor followed by supplementary hoe-weeding in the late season. This showed that the gain in revenue from three hoeweedings compared to herbicide plus hoe-weeding treatments was nullified by accumulated labour cost for hoe weeding. Application of butachlor and propaben plus hoe weeding gave higher gross margin and cost-benefit ratio than three hoe-weeding treatments in both seasons. The highest gross margin (\$922.2 and \$885.8 in the early and late seasons, respectively) was recorded with butachlor at 2 $\mathrm{kg}$ a.i ha ${ }^{-1}$ plus hoe weeding. The highest cost-benefit ratio (2.2 and 2.3 in the early and late seasons, respectively) was recorded with propaben and butachlor each followed by hoe-weeding (Table 4). This showed that pre-emergence herbicides plus hoe-weeding provided high yield at relatively lower cost. This result have corroborated previous report of Khaliq et al. (2012) that weed control with herbicides provided higher gross margin and cost-benefit than manual weeding. Lowest revenue, gross margin and costbenefit ratio ( 0.5 and 0.2 in the early and late seasons, respectively) was recorded in the weedy plot (Table 4).

\section{CONCLUSION}

This study demonstrated the effectiveness of integrated weed management for efficient weed management, higher pod yield, revenue, gross margin and cost-benefit ratio than sole herbicide application or manual hoe weeding in groundnut production in both early and late seasons. Farmers can therefore reduce labour cost for manual hoe weeding with pre-emergence application of butachlor or propaben. This can be supplemented by one hoe weeding at 6 weeks after sowing for season-long weed management, optimum groundnut pod yield and ultimately higher profit in groundnut production.

\section{REFERENCES}

Adigun, J. A., Lagoke, S. T. O. (2003). Weed control in trans- planted rain and irrigated tomatoes in the Nigerian savanna. Nigerian Journal of Weed Science, 16, 23-29.

Adigun, J. A., Adeyemi, O. R., Lagoke, S. T. O., Olorunmaiye, P M., Daramola, O. S., Babatunde, O. A. (2016). Influence of inter-row spacing and weed control in groundnut (Arachis hypogeae L.) Journal of Agricultural Science and Environment, 16(1), 22-35.

Adigun, J. A., Adeyemi, O. R., Daramola, O. S., Odueme, P. U., Fadeyi, O. J. (2017). Growth and yield performance of groundnut (Arachis hypogeae L.) as affected by row spacing and weed control methods in the Nigerian forest-savannah transition zone. Nigerian Journal of Ecology, 16(1), 22-35.

Adigun, J. A., Daramola, O. S., Adeyemi, O. R., Ogungbesan A. (2018). Impact of nitrogen levels and weed control methods on growth and yield of okra (Abelmoschus esculentus (L.) Moench) in the Nigerian forest-savanna. Journal of Experimental Agriculture International, 20(2), 1-11. https://doi. org/10.9734/JEAI/2018/39107

Bado, B. V., Lompo, F., Bationo, A. (2012). Nitrogen recoveries and yields improvement in cowpea-sorghum and fallowsorghum rotations in West Africa Savannah. Journal of Agricultural Science and Technology, 2758-2767.

Bhagirath, S. C., Chauhan, J. H., Opeña, L. (2013). Effect of plant spacing on growth and grain yield of soybean. American Journal of Plant Sciences, 4, 2011-2014. https://doi. org/10.4236/ajps.2013.410251

Birthal, P. S., Nigam, S. N., Narayanan, A. V., Kareem, K. A. (2011). An economic assessment of the potential benefits of breeding for drought tolerance in crops: A case of groundnut in India. Research Bulletin no. 25. Patancheru: International Crops Research Institute for the Semi-Arid Tropics.

Chauhan, B. S., Singh, R. G., Mahajan, G. (2012). Ecology and management of weeds under conservation agriculture: A review. Crop Protection, 38, 57-65. https://doi.org/10.1016/j. cropro.2012.03.010

Daramola, O. S., Adeyemi, O. R., Adigun J. A., Adejuyigbe, C. O. (2019). Crop-weed association and inter-relationships in soybean-weed ecosystem in the transition zone of southwest Nigeria. Nigerian Journal of Ecology 17(2), 97-114.

Daramola, O. S., Adeyemi, O. R., Adigun J. A., Adejuyigbe, C. O. (2020). Weed interference and control as affected by row spacing in the transition zone of south-west Nigeria. Journal of crop Improvement, 34(1), 103-121. https://doi.org/10.1080 /15427528.2019.1674759

Datta, A., Ullah, H., Tursun, N., Pornprom, T., Knezevic, S. Z., Chauhan, B. S. (2017). Managing weeds using crop competition in soybean (Glycine max (L.) Merr.) Crop protection, 95, 60-68. https://doi.org/10.1016/j.cropro.2016.09.005

Food and Agricultural Organizations of the United Nations (FAOSATAT). Statistical Data Base; Food and Agricultural Organizations of the United Nations: Rome, Italy, 2018.

Gouse, M., Jenifer, P., Colin, T. (2006). Output and labour effects of GM maize and minimum tillage in a communal area of Kwazulu-Natal. Journal of Development Perspectives, 2(2), 71-86. https://doi.org/10.35648/20.500.12413/11781/ii259

Imoloame, E. O. (2014). The effects of different weed control methods on weed infestation, growth and yield of soybeans (Glycine $\max (\mathrm{L})$ Merrill) in the southern guinea sa- 
vanna of Nigeria. Agro search, 14(2), 129-143. https://doi. org/10.4314/agrosh.v14i2.4

Janila, P., Nigam, S. N., Manish K., Pandey, P., Nagesh, R., Varshney, K. (2013). Groundnut improvement: use of genetic and genomic tools. Frontier in Plant Science, 4, 23 https:// doi.org/10.3389/fpls.2013.00023.

Kercher, S. M., Frieswyk C. B., Zedler, J. B (2003). Effects of sampling teams and estimation methods on the assessment of plant cover. Journal of Vegetable Science, 14, 899-906. https://doi.org/10.1111/j.1654-1103.2003.tb02223.x

Khaliq, A., Matloob. A., Ahmed, N., Rasul, F., Awan, I. U. (2012). Late POST emergence chemical weed control in direct seeded fine rice. Journal of Animal and Plant Science, 22, 1101-1106.

Maurice, D. C., Amaza, P. S., Tella. M. O. (2005). Profitability of rice based cropping patterns among dry season Fadama Farmers in Adamawa State, Nigeria. Applied and Tropical Agriculture, 10, 13-16.

Menalled, F. D., Gross, K. L., Hammond, M. (2001). Weed aboveground and seed bank community responses to agricultural management systems. Ecology Application, 11, 1586-1601. https://doi.org/10.1890/10510761(2001)011[1586:WAASCR]2.0.CO;2

Mishra, J. S., Rao, A. N., Singh, V. P., Kumar, R. (2017). Weed management in major field crops. Advances in Weed Management, 4, 1-21.

Nikoa, R, M., Owen, D. K., Swanton. C. J. (2015). Weed Abundance, Distribution, Diversity, and Community Analyses. Weed Science, 63, 64-90. https://doi.org/10.1614/WS-D-1300075.1

Ojelade, O. B., Lagoke, S. T. O., Adigun, J. A., Babalola, O. A.,
Daramola, O. S., Osipitan, O. A. (2018). Intra-row spacing and weed control influence on growth and yield of groundnut (Arachis hypogea L.). Journal of Agricultural Science, 6(4), 1-11.

Overfield, D, Murithi, M. F., Muthamia, J. N., Ouma, J. O., Birungi, K. F., Maina, J. M...Terry, P. T. (2001). Analysis of the constraints to adoption of herbicides by smallholder maize growers in Kenya and Uganda. Proceedings of the BCPC Conference Weeds 2001, 907-912. Lagos, Nigeria.

Pannell, D. J., Marshall, G. R., Barr, N., Curtis, A., Vanclay, F., Wilkinson, R. (2006). Understanding and promoting adoption of conservation practices by rural landholders. Australian Journal of Experimental Agriculture, 46(11), 1407-1424. https://doi.org/10.1071/EA05037

Sepat, S., Thierfelder, C., Sharma, A. R., Pavuluri, K., Kumar, D., Iquebal, M. A., Verma, A. (2017). Effects of weed control strategy on weed dynamics, soybean productivity and profitability under conservation agriculture. Field Crops Research, 210, 61-70. https://doi.org/10.1016/j.fcr.2017.05.017

Shadiul, H. B., Min, Y. E, Romij, M. D, Tea, S. P, Hang, W. K, Do, S. K, Park, K. W. (2011). Weed population dynamics under climatic change. Asian journal of Turf Grass Science, 25(1), 174-182.

Sogut, T., Ozturk, F., Kizil, S.(2016). Effect of sowing time on peanut (Arachis hypogea L.) cultivars: II. Fatty acid composition. Agriculture and Agricultural Science Procedia, 10(1), 76-82. https://doi.org/10.1016/j.aaspro.2016.09.018

Tunku, P., Lagoke, S. T. O., Ishaya, D. B. (2007). Evaluation of herbicides for weed control in irrigated garlic at Samaru, Nigeria. Crop Protection, 26, 642-646. https://doi. org/10.1016/j.cropro.2006.05.017 